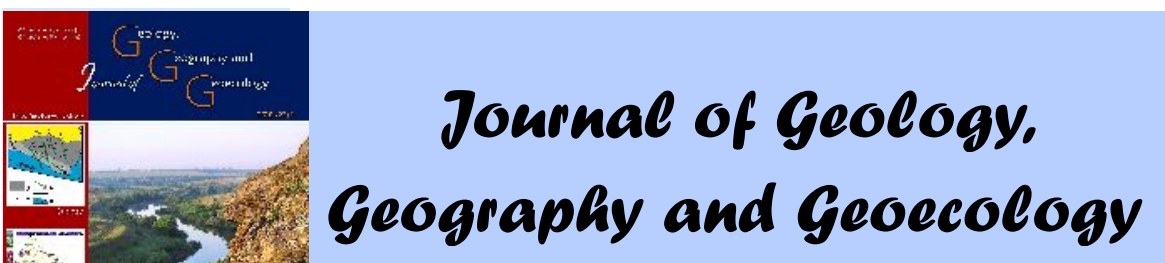

Journal home page: geology-dnu-dp.ua

\title{
Mineralogical features of the clastic dykes of the Eastern Carpathians Skybova zone
}

\author{
V. I. lokhin ${ }^{1}$, S. V. Tikhlivets ${ }^{2}$, A. V. Murovska ${ }^{3}$, A. V. Puhach ${ }^{1}$ \\ ${ }^{1}$ Donetsk National Technical University, Pokrovsk, Ukraine \\ e-mail: vikalex1414@gmail.com \\ ${ }^{2}$ Kryvyi Rih National University, Kryvyi Rih, Ukraine \\ e-mail: tikhlivets.svetlana@gmail.com \\ ${ }^{3}$ The Institute of Geophysics of the National Academy of Sciences of Ukraine, Kyiv, Ukraine, \\ e-mail: vikalex1414@gmail.com
}

Received 03.03.2018;

Received in revised form 11.04.2018;

Accepted 16.06.2018

Summary. We determined several areas with outcrops of clastic dikes which occur in the rocks of the Menilite suite of the Upper Paleogene period in the so-called Skybova zone [Ukr. кибов зон - the largest tectonic zone within the Carpathian folded structure. The word "skyba" derived from Polish, and is used in relation to nappe - Translator's Note ] of the Eastern Carpathians. The objective of this article is to reveal the peculiarities of bedding, mineralogical composition and structural-texture peculiarities of the clastic dikes of the Sukyl, Stryi and Skhidnytsia river basins. During our research, we used the method of field structural-geological surveys, traditional method of laboratory analysis of mineralogical-petrographic composition of rocks in thin sections. As a result, we studied the conditions of bedding of clastic dikes, mineral composition and structural-texture peculiarities. We determined that the dikes are represented by aleuro-sandstone and aleurolite with quartz-carbonate cement. Aleurolite most often represents pre-selvage parts of dikes. Mineral grains are mostly formed by quartz of different degrees of roundness. In the selvages of the studied dikes, we observed a decrease in the sizes of mineral grains, enrichment of these parts of dikes by organic compound, increase in the content of carbonate minerals in the rock cement and numerous microdeformations of mineral grains. Also we determined an insignificant content of ore minerals in some studied plots. Additional analysis conducted for a polished sample which characterizes the vertical section of dike in the area of the river Sukyl allowed us to determine the structural signs in its selvages, indicating injection character of dikes ' upward introduction to the bearing rocks. We studied the microdeformation of dikes' mineral grains, which are represented by veinles, microfaults and microshifts with clear mixing of their fragments. The obtained results indicate the formation of clastic dikes of the Skybova zone of the Eastern Carpathians in conditions of compression, when relatively flexible material of selvages of the dikes, represented by carbonates and organic compound, contributed to the introduction of the latter to the layer of flysch through the system of tectonic faults of north-west stretch.

Key words: Eastern Carpathians, Skybova zone, argillites, aleurolites, aleuro-sandstones, clastic dikes, mineral composition of the clastic dikes, microdeformations.

\section{інер логічні особливості кл стичних д йок кибової зони хідних рп т}

$$
\begin{aligned}
& \text {. . льохін }{ }^{1}, \text {. . ихливець }{ }^{2}, \text {. . } \text { уровськ }^{3}, \text {. . уг } \mathbf{4}^{1} \\
& 1 \text { «онецький н ціон льний технічний університет», окровськ, кр їн, } \\
& \text { e-mail: vikalex1414@gmail.com } \\
& 2 \text { «риворізький н иіон льний університет», ривий і2, кр їн, }
\end{aligned}
$$

нот ція. ст новлено кільк ділянок із виход ми кл стичних д йок, які тр пляються в пород х менілітової світи верхнього п леогену в кибовій зоні хідних ртп т. ет дослідження - висвітлення особливостей з ляг ння, мінер логічного скл ду і структурно-текстурних особливостей кл стичних д йок 6 сейнів рік укіль, трий і хідниця. стосов но методику польових структурно-геологічних досліджень, тр диційну методику л бор торних досліджень мінер лого-петрогр фічного скл ду порід у шліф х. результ ті вивчено умови з ляг ння кл стичних д йок, досліджено мінер льний скл д і структурнотекстурні особливості. ст новлено, що д йки предст влені левропісщ ник ми й левроліт ми із кв рц-к рбон тним цементом. 
левролітом ч стіше предст влені приз льб ндові ч стини д йок. інер льні зерн скл дені в основному кв рцом різного ступеня обк т ності. 3 льб нд х вивчених д йок відмічено зменшення розмірів мінер льних зерен, зб г чення цих ділянок д йок орг нічною речовиною, збільшення вмісту к рбон тних мінер лів у цементі породи і численні мікродеоформ ції зерен мінер лів. кож уст новлено незн чний вміст рудних мінер лів у деяких вивчених ділянк $\mathrm{x}$.

од ткове вивчення поліров ного зр зк , який х р ктеризує вертик льний перетин д йки $\mathrm{p}$ йону р. укіль, дозволило в її з льб нд х уст новити структурні озн ки ін'єкційного х р ктеру проникнення д йки у вмісні породи в н прямку знизу вгору.

ивчено мікродеформ ції зерен мінер лів д йок, які предст влені прожилк ми, мікротріщин ми і мікрозсув ми з видимим зміщенням їх фр гментів.

трим ні результ ти вк зують н формув ння кл стичних д йок кибової зони хідних рп тв умов хстиску, коли відносно пл стичний м тері лз льб ндів д йок, предст влений к рбон т ми з орг нічною речовиною, сприяє проникненню ост нніх у товщу флішу по системі тектонічних тріщин північно-з хідного простяг ння.

лючові слов : хідні рп ти, кибов зон, ргіліти, левроліти, левропіщ ники, кл стичні д йки, мінер льний скл д кл стичних д йок, мікродеформ иії

Introduction. Relevance of the problem and presentation of the task. Dikes are a broadly distributed form of rock bedding. They are stretched bodies limited by more or less regular surfaces which cross-cut the bearing rocks vertically or at a steep angle. There are magmatic and clastic dikes. The difference between them lies in their constituent material: clastic dikes are filled with allothigenic material. The condition of bedding, mechanisms of their formation, peculiarities of morphology and composition are substantially described in foreign literature in English (Aspler, Donaldson, 1985; Eyal , 1988., Kenkmann, 2003).

The relevance of the problem of studying the clastic dikes in Ukraine, particularly in the Ukrainian Carpathians, lies in the insufficient study of their bedding conditions, mineralogical-petrographic composition, mechanisms and conditions of their formation. The peculiarities of the deformations of dikes has also remained unstudied.

Currently, clastic dikes in Ukraine are practically unstudied, whereas in many foreign journals, this topic is widely discussed. The studies by our foreign colleagues in detail describe mineralogicalpetrographic peculiarities of dikes, their structure, conditions of bedding and relationship with deep horizons, mechanisms of formation of clastic dikes (Aspler., Donaldson, 1985., Eya, 1988., Kenkmann, 2003).

The outcrops of clastic dikes at the head of the river Sukyl (Skybova zone of the Eastern Carpathians) were mentioned in the works by U. Vykhot ' and I. Bubnjak (Vykhot', Bubnjak, 2011). In the Eastern Carpathians, I. Bubnjak et al. determined several areas with outcrops of clastic dikes - in the rocks of the Menilite suite of the Upper Paleogene near the Skhidnytsia village, in the flint deposits near Rybnik village in Drohobych Raion and in the area of Boryslav (Bubnyak, Buchynska, Vnuk, 2013). The authors connect the formation of clastic dikes with earthquakes before the main phase of the Alpine orogeny. Also, the researchers emphasize the deformation of these dikes. However, these works provide no detailed analysis of the mineral composition and structural-textural peculiarities of the clastic dikes in this region, conditions of their bedding, characteristics of their morphology and their change in space, or the distinctive signs of their formation mechanisms.

A more detailed characteristic of clastic dikes with description of the formation mechanism, the direction of movement of the dikes " material and usage of clastic dikes for determining the overturned bedding of the rocks on the example of the neighboring region is provided by the Polish researchers Barmuta. Et al (Barmuta, Barmuta, Golonka, 2014).

The first detailed description of the dikes" composition, conditions of their bedding, mechanisms of their formation and their signs was made by the abovementioned authors for clastic dikes of the area in the Bubnyshche (the valley of the Sukyl) ( lokhin, 2015, lokhin, Tikhlivets, 2016).

The objective of this paper is to enlarge the territorial area of the study of clastic dikes by performing the following tasks: 1) detailed survey of the bedding conditions of the dikes in the area of the Sukyl river, the basin of the Stryi and Skhidnytsia rivers; 2) study the peculiarities of the structure, texture, mineral and petrographic composition of the dikes in these regions using the standard and microscopic methods; 3) to conduct a comparative characteristic of the dikes in different areas of the Eastern Carpathians; 4) characterize the formation mechanism of the clastic dikes.

Methodology and methods. During the study, we used the methods of field structural-geological survey and the traditional methodic of laboratory analysis of the mineralogical-petrographic composition of the rocks in thin sections. During the field surveys, we studied the dike outcrops and the containing rocks, measured the elements of bedding of the rocks and dikes, selected using standard methods spatially-orientated samples of the clastic dikes in each of the three plots. A transparent and polished thin section was made out of each selected sample. At the same time, the thin sections of the dike rock - 
horizontal and vertical, taken lengthways and as cross-cuts in relation to the dike strike. Their microscopic analysis was conducted in reflecting light and penetrating light using the standard method of serial petrographic and mineragraphic microscopes and Olympus E-500 photo camera for microscopic photos. During the microscopic analyses of the rocks, special attention was focused on the variations of the mineral composition and the structural-texture peculiarities in the central and pre-selvage parts of the clastic dikes.

The obtained results and their analysis. In the area of the Sukyl river valley near Bubnushche village, the clastic dikes outcrop through the rocks of the Upper Paleogene Menilite suite ( lokhin, 2015). The containing rocks are represented by argillites, aleurolites (occur more rarely) and grey aphanitic carbonate rocks. The argillites lay under the carbonate rocks which, in the lower part of the horizon, contain a layer of cavernous dark-grey limestone enriched with organic material. The monocline bedding position of the rocks with a $20-30^{\circ}$ angle of dip towards south-west is proved by the angle azimuth of $200-220^{\circ}$.

In the area of the Sukyl River, eight clastic dikes of 2 to $12 \mathrm{~cm}$ thickness were found (Fig. 1).

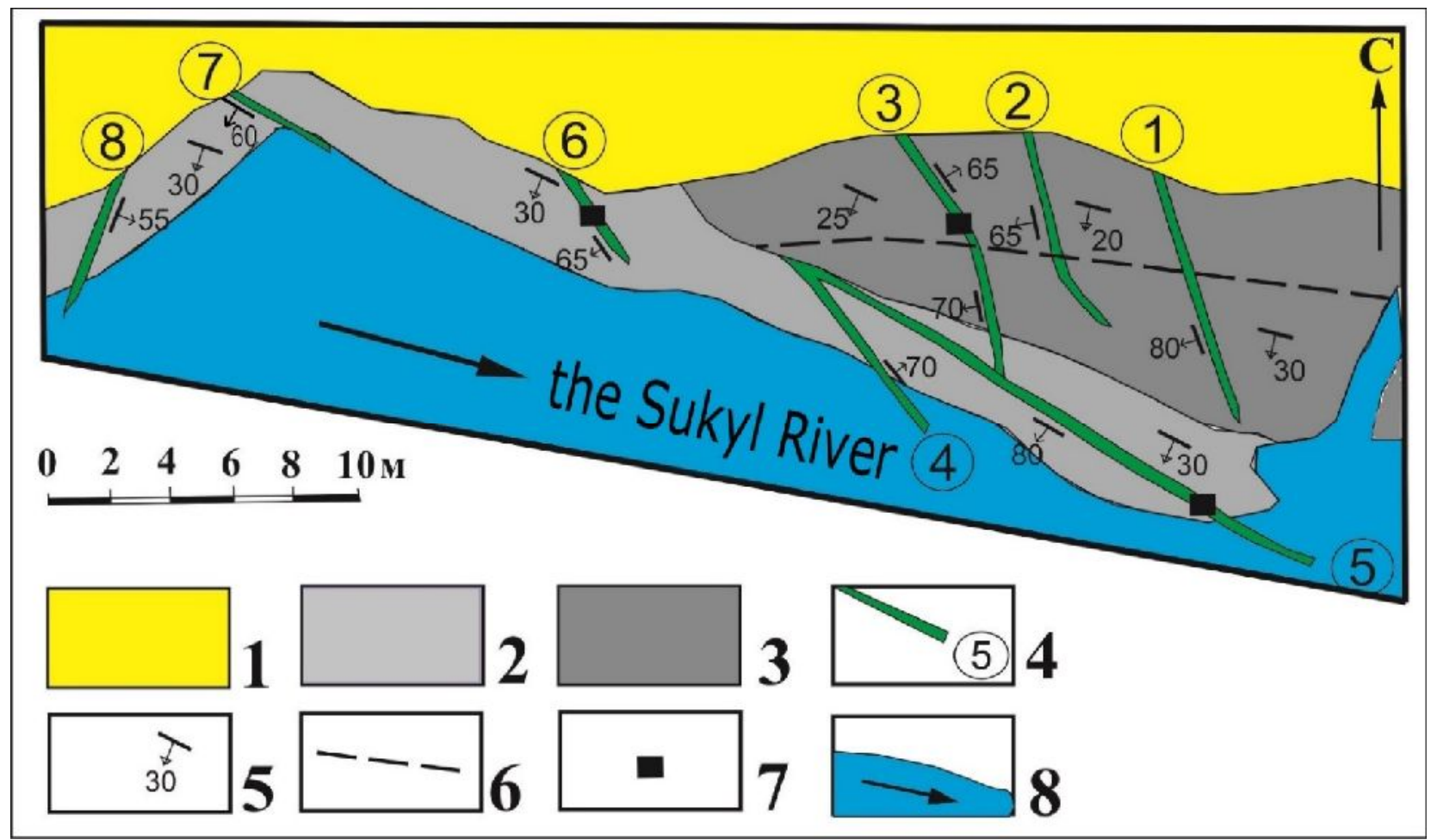

Fig. 1. Schematic geological plan of the area of the clastic dike outcrops:

1 - overburden deposits; 2 - carbonate rocks; 3 - argillites; 4 - clastic dikes with their numbers (irrespective of the scale); 5 - the strata bedding elements of the containing rocks and dikes; 6 - rupture; 7 - the area where the orientated samples for microscopic analysis were selected; the Sukyl river and direction of its current.

The dikes transect the argillites and carbonate rocks. Most of them have north-west strikes and was observed from the distance from 2 to $15 \mathrm{~m}$. Field survey of the dike form, their petrographic composition and relationship with the containing rocks indicated that the thickness and the dip direction of certain dikes change along the strike. According to petrographic composition, the dikes vary insignificantly: most of them are composed of fine-grained sandstone gradually followed by aleurolite.

The most representative dikes of the area of the Sukyl river are the dikes № 3, 5 and 6, for a detailed analysis of which, we selected samples using the standard methods and studied them macro- and microscopically.

As a result of the field survey of dike forms, their macroscopic peculiarities and relationship with the containing rocks, we determined that the thickness of dikes and their dip direction change along the strike; petrographic composition of the dikes differed insignificantly. One dike (dike № 5) had a high content of carbonate material, which manifested in reaction with hydrochloric acid.

During the study of the thickest clastic dike in this area (dike № 3), we determined change in its thickness along strike and dip direction after crossing the sub-latitudal faults. The relationship between the dike and the containing rocks (argillites) is characterized by rounded curves of the argillites' contacts under the dike, which indicates the injection mechanism of the formation and the direction of its integration (Fig. 2). 


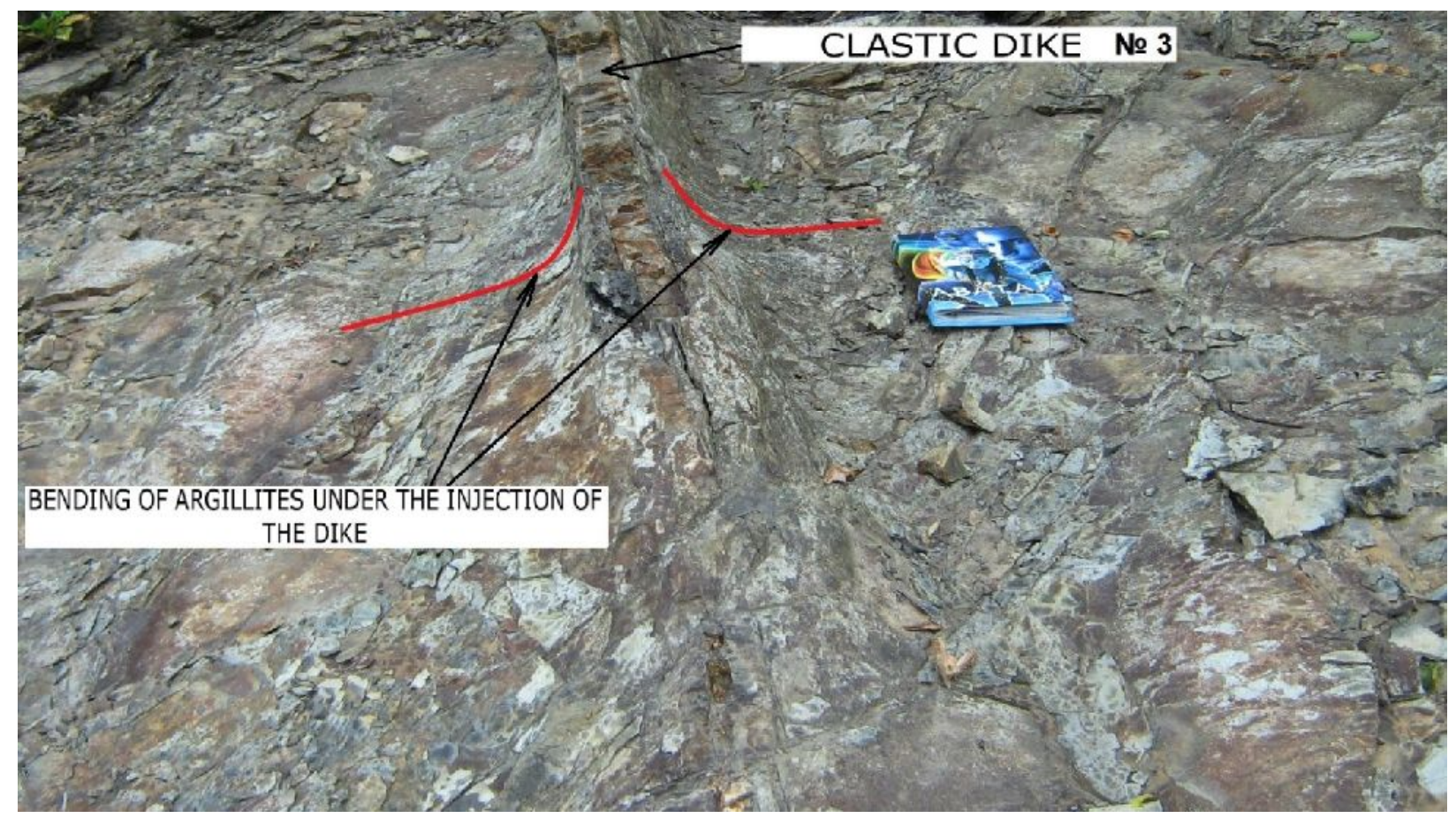

Fig. 2. The pattern of relationship between the clastic dike №3 and the containing argillites, which indicates the injection mechanism and the direction of the dike's integration.

The clastic dike №3 is characterized by a clearly zonal structure. Its pre-selvage part is represented by dark grey to black flint. The central part of the dike is composed of grey flint aleuro-sandstone (Fig. 3), selvage - aleurolite with veinlet texture (Fig. 4). Texture of the main rock mass is massive; the structure is aleurolitic, aleuropsammitic, psammitic, average-sorted. The content of fragments is $65-70 \%$, cement $-35-30 \%$. Mineral composition of the rocks in different sections of the dike № 3 is identical. The main minerals are represented by quartz (70-80 vol\%) and glauconite (4-15\%). Plagioclase, microcline, sericite, muscovite, goethite, ore mineral were also present in small amounts ( 0.5 to $5 \%$ each).

The cement is quartz-carbonate $(20 \%$ of quartz, $80 \%$ of carbonate) contact-basaltic. The structure of the cement is microgranoblastic. The dike rock contains injections of organic compound (Fig. 3a). The quartz particles are sometimes corroded and segmented by microfaults, and characterized by wavy type of extinction.
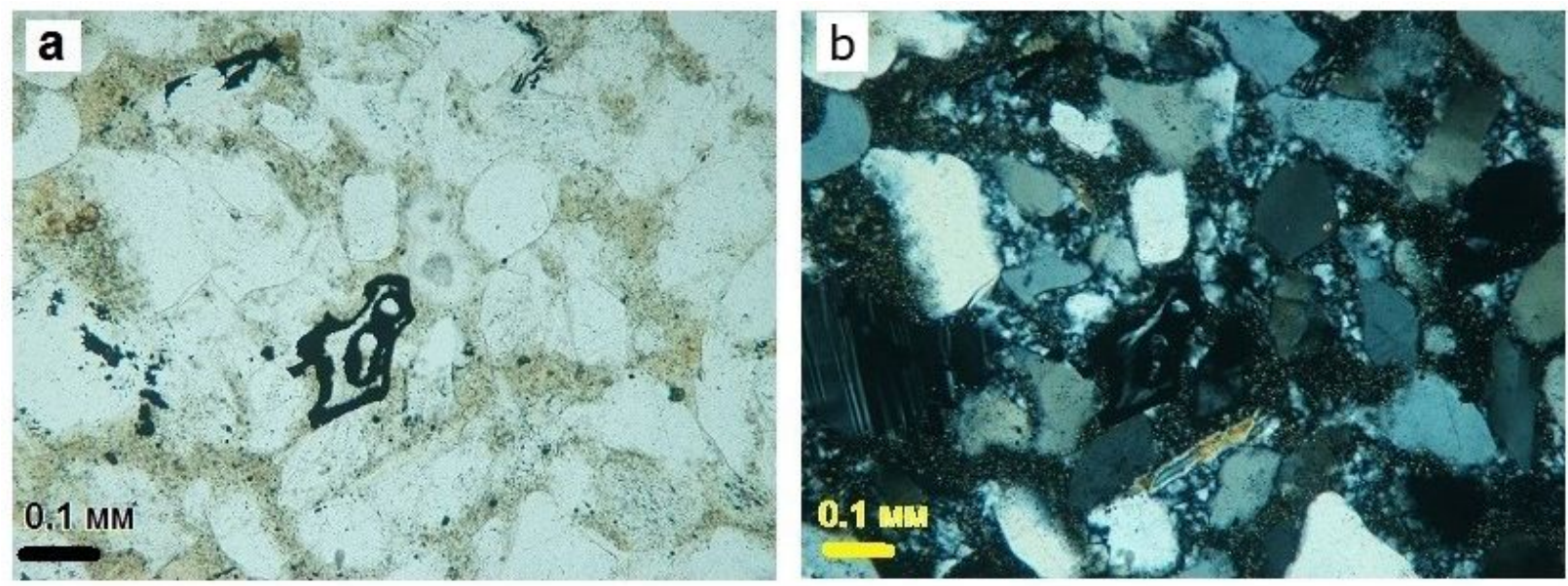

Fig. 3. Peculiarities of mineral composition and structure of the rock which forms the central part of the dike № 3. a - white - quartz; green - glauconite; black - organic compound;

$\mathrm{b}$ - white to dark grey - quartz; dark green - glauconite; black - organic compound.

Light which penetrates; no analyser (a) and with analyser (b). 
In the zone of the dike selvage, the size of the fragments decreases, the amount of cement increases to $50 \%$ and higher. Here, the composition of the cement slightly changes - $80 \%$ is composed of organic compound and iron hydroxides, and $20 \%$ is composed of veinlets of carbonate minerals. The cementation type is porous-basal. The structure of the cement is amorphic. In this zone, microdeformations are especially intense (Fig. 4). These peculiarities indicate the compression conditions, in which the integration of dikes into the flysch occurred.

The dike № 5 in relation to the bedding conditions and petrographic composition slightly differs from the dike № 3. It transects only the carbonate rocks and is formed by greenish-grey fine-grained rock, which boils under the influence of hydrochlo- ric acid, which indicates the high content of carbonate material in the dike rock. During a more detailed macroscopic analysis with a magnifying glass, it was determined that the rock is pierced by numerous microfaults filled with carbonate material. The dike was monitored at the distance of more than 15 $\mathrm{m}$, the average thickness is $5-6 \mathrm{~cm}$, the azimuth of the strike equals $305^{\circ}$, the dip direction is sharp and directed south-west. It is characterized by a zonal structure. The main part of the dike is composed of greenish-grey fine-grained rock, where small green injections of glauconite of up to $0.5 \mathrm{~mm}$ occur. Its pre-contact parts are represented by dark grey to black rock with high content of glauconite. The dark color indicates a heightened content of organic compound.
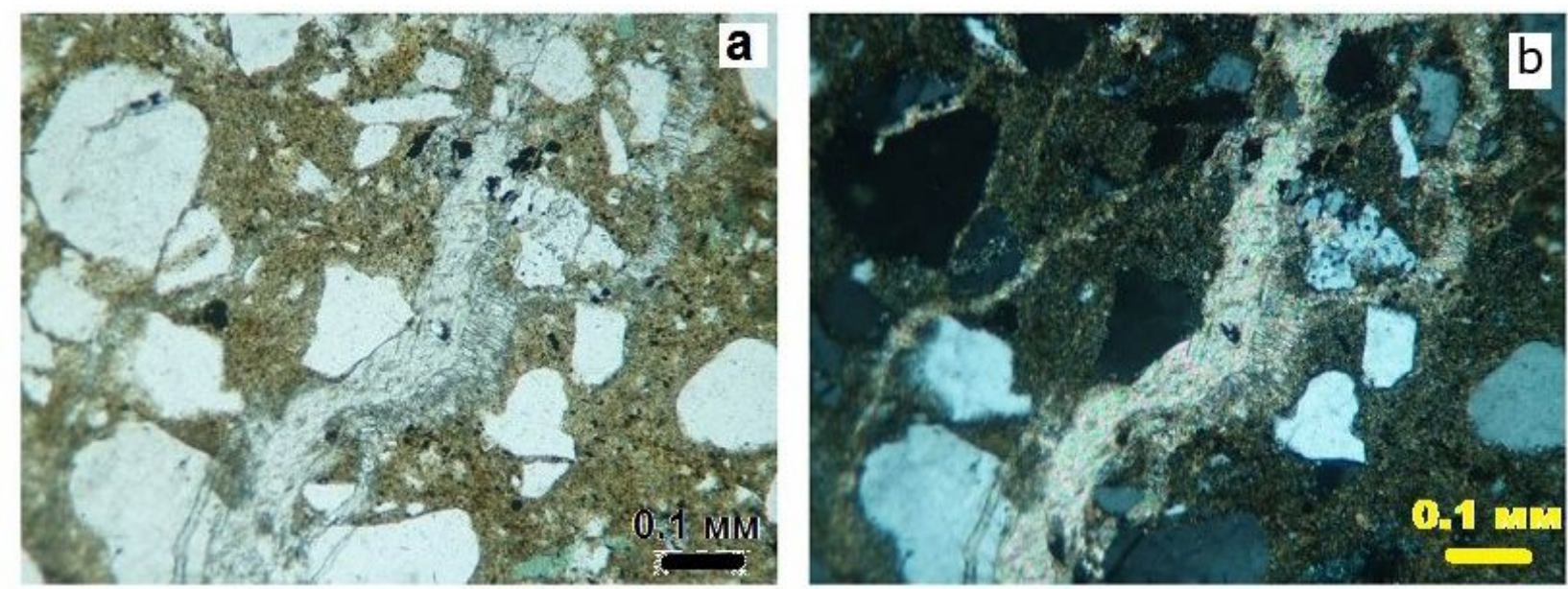

Fig. 4. Peculiarities of mineral composition and structure of rock which forms the selvage part of the dike № 3 (horizontal section to the strike of dike).

a - white - quartz; green - glauconite, bright grey - carbonate; brown to black - organic compound; b - grey to black - quartz; colored - carbonates; dark brown - organic compound.

Light which penetrates, without (a) and with (b) analyser.

During the analysis of the material of the dike №5 using penetrating light, we determined that its main body is composed of aleurosandstone. The texture is massive, the structure is aleuropsammitic average-grained. The fragments make up $70 \%$ of the rock volume, cement - $30 \%$. In relation to the extent of roundness, the fragments are distributed as follows: rounded - $71 \%$, insignificantly rounded $-20 \%$, not rounded $-9 \%$. The cement is quartz-carbonate (carbonate - 90\%, quartz - 10\%) and contact-basal. The structure of the cement is crystallne, pelitomorphic, granoblastic.

In the rocks of the dike selvage, we observed an increase in the amount of cement and in its composition - carbonate material and organic compound. In the rocks of this part of the dike, we found an increased amount of ore material (around 4\%). We observed numerous tectonic microdeformations - microfaults and microshifts. The latter shift the fragments of quartzitic grains in one direction, which could indicate an insignificant horizontal component of the dike"s integration to the flysch layer in the conditions of compression.

Microscopic analysis of the dike №5 was conducted not only by transparent light, but also by reflected light. The study of the polished section which reflects its vertical section, enabled us to determine a rapid transition from the aleurosandstone of the main body to aleurolite in the dike's selvage. In the rock, we found cavities and microfaults filled with organic compound. We observed isometric grains of pyrite (Fig. 5). In the dike, we also found magnetite which occurs in the form of separate idiomorphic grains and as injections to the quartz. Other discovered ore minerals were goethite and ramified amorphic grains of marcasite. The amount of ore minerals in the selvage zone is larger than in the main body of the dike.

The analysis of the mineral composition and structural-texture peculiarities of the dike № 6 indicated that the rock of this dike is represented by aleurolite. The rock texture is massive, the structure is 
aleurolitic and average-sorted. The fragments make up $60 \%$, the cement - $40 \%$. In terms of roundness, the fragments are not rounded (80\%), insignificantly rounded (19\%), rounded (1\%). Mineral composition of the dike's fragments is represented mainly by quartz - $-93.5 \mathrm{vol} \%$. The content of glauconite is up to 4 vol \%. Other minerals were: ore minerals $1.5 \mathrm{vol} \%$; plagioclase $-0.5 \mathrm{vol} \%$; zircon $-0.2 \mathrm{vol}$ $\%$; sericite -0.2 vol $\%$; muscovite -0.1 vol $\%$.

The cement of the rock of the clastic dike № 6 slightly differs from the cement of the dike № 3. In the cement of the first dike, the content of quartz is up to $80 \%$. The content of organic compound is up to $15 \%$, carbonate $-5 \%$. The type of cementation is basal. The structure of the cement is microgranoblastic.

As a result of the conducted studies, we can conclude that the clastic dikes of the area of the Sukyl river have no significant differences. They are close in mineralogical and petrographic composition, the difference occurs in the compound of the cementing material and percentage of the content of the main minerals, and also in the amount of ore minerals.
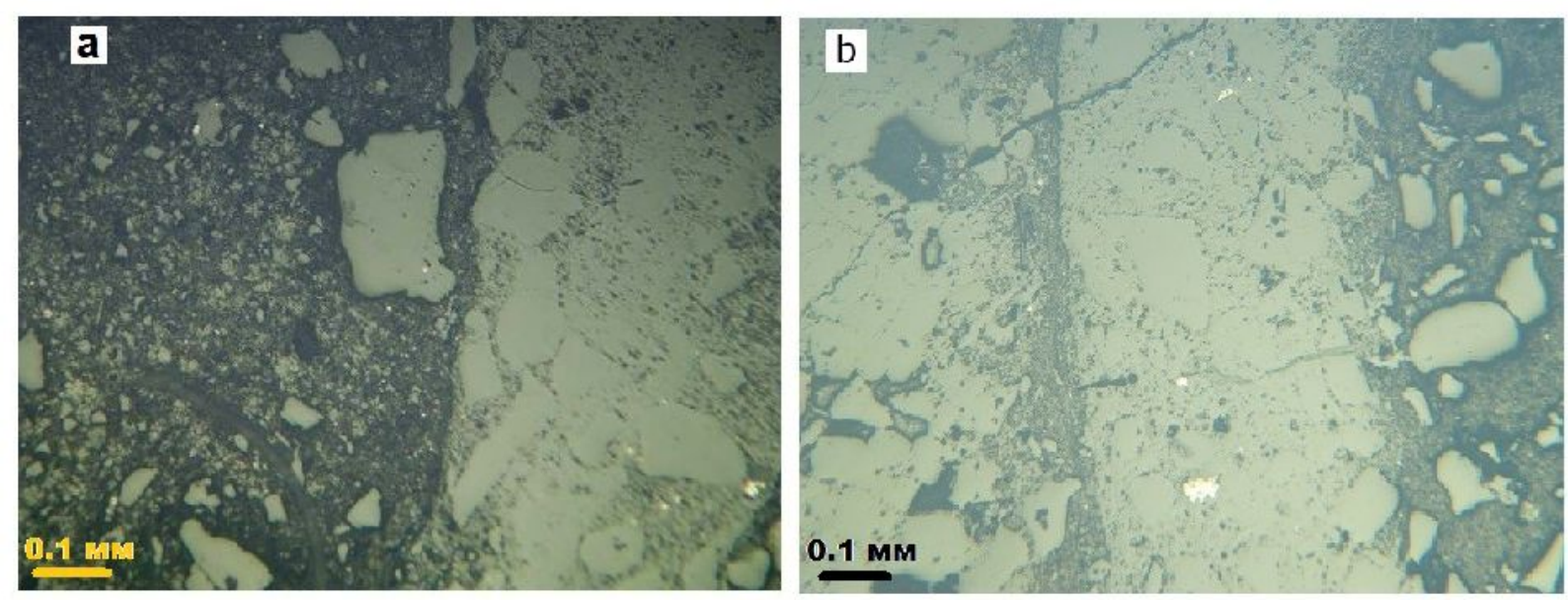

Fig. 5. Vertical section of the clastic dike №5 in the area of the Sukyl river.

a - pre-selvage zone of the dike; b - dike's selvage; grey - quartz; dark grey - carbonate cement; yellow - grains of pyrite.

In Eastern Carpathians, the outcrops of the dikes were also found in the areas of the Skhidnytsia and Stryi rivers (Rybnik area). On the left bank of the Skhidnytsia, the outcrops stretch along $100 \mathrm{~m}$. The height of the cliff which opens the flysch layer is $15 \mathrm{~m}$. Thickness of the clastic dikes in this area ranges from 10 to $30 \mathrm{~cm}$. The largest thickness is typical for the eastern dike. Their bedding significantly varies, intense deformations of the dike bodies occur (Fig. 6a, b). The eastern dike in the lower part is divided into blocks (boudinages) shifted in echelon one to another (Fig. 6 a), and the western dike, in the lower part, is crumpled into a small fold and disrupted (Fig. 6 b). In the dikes, we observed numerous polished surfaces.

In the area of the Stryi river, rocky outcrops stretch for more than $100 \mathrm{~km}$, within which one clastic dike was found. It has a north-west strike (azimuth of the strike is $330^{\circ}$ ) with dip direction towards north-east at the angle of $80^{\circ}$. The dike's thickness ranges from 8 to $15 \mathrm{~cm}$. The dike is significantly deformed, it is especially clear in its lower part. We found boudinage, many subhorizontal faults, polished surfaces (Fig. $6 \mathrm{~d}$ ). At the height of $2.5 \mathrm{~m}$, the clastic dike is cut by the strike-slip fault in the flint rocks which characterize the lower horizon of the Menilite suite in contact with non-fragmented Eo- cene deposits. These rocks have a south-west dip direction at an angle of $25-40^{\circ}$. We observed a shift of the rocks in the north-east strike (strike slip) with north-west dip direction at an angle of $40-50^{\circ}$.

Microscopic studies were conducted using the standard method with a polarization microscope. The analysis of mineral composition and structuraltexture peculiarities of clastic dikes in the area of the Skhidnytsia river indicated that the rock of this dike is represented by aleurolite and aleurosandstone with different percentage ratio of fragments and cement. The texture of the rock is massive, the structure is aleurolitic and average-grained aleuro-sandstone. In some dikes, the number of the fragments equals $80 \%$, the cement $-20 \%$. According to the extent of roundness, the fragments are not rounded $(70 \%)$, insignificantly rounded $(25 \%)$, rounded $(5 \%)$. The fragments are formed by quartz $(79-87$ vol \%), glauconite $(2-10 \mathrm{vol} \%)$, feld spar $(0.5-5$ vol \%), ore mineral (2-8 vol \%). The number of glauconite grains increased to 13 vol \% near the dikes selvage. The cement of the clastic dikes is represented by carbonate material with organic compound and mica. The amount of carbonate rapidly increases in the cement of the dikes' selvages to $90 \mathrm{vol} \%$. The same pattern was observed for the organic compound (Fig. 7). 

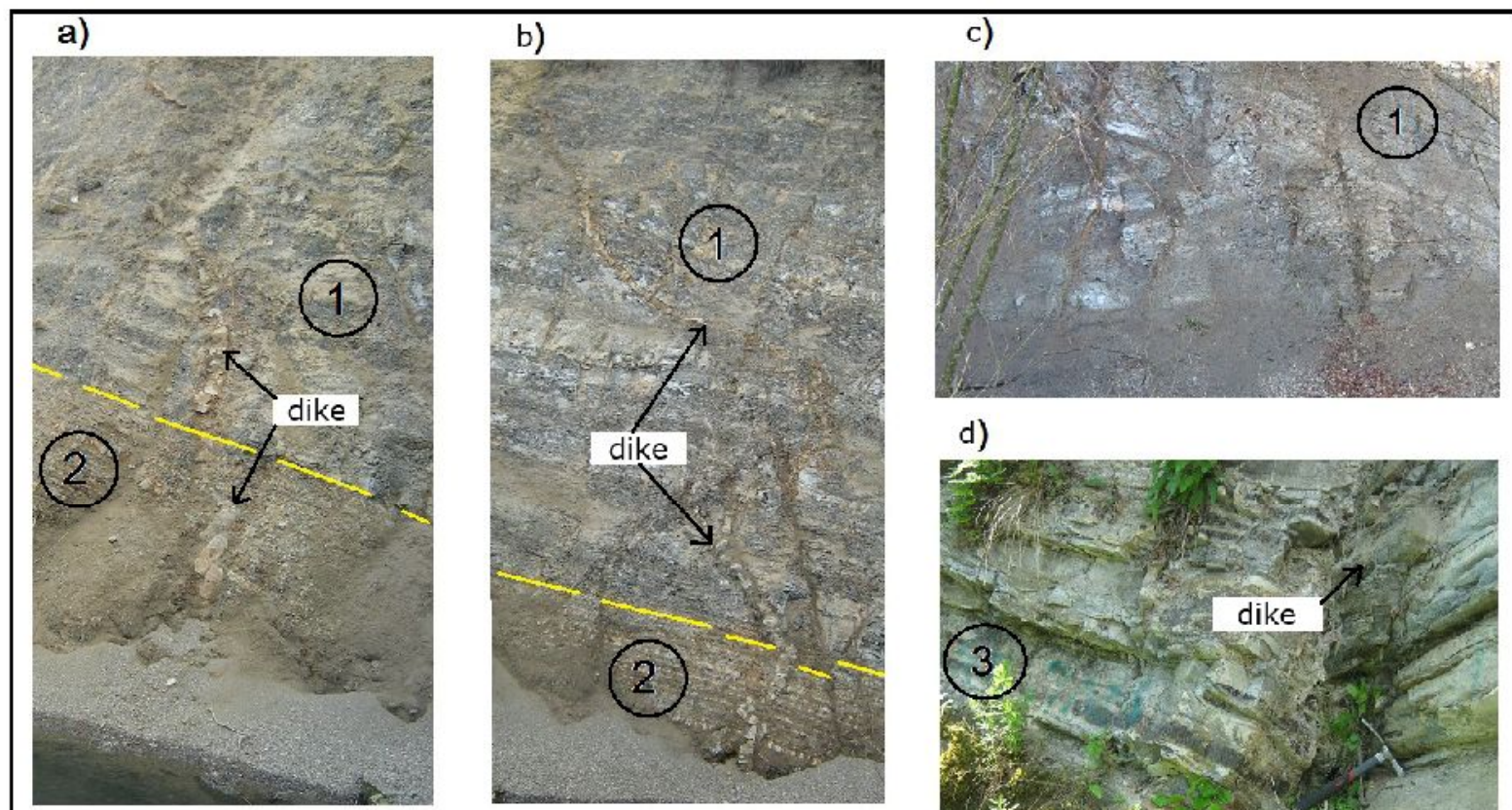

d)

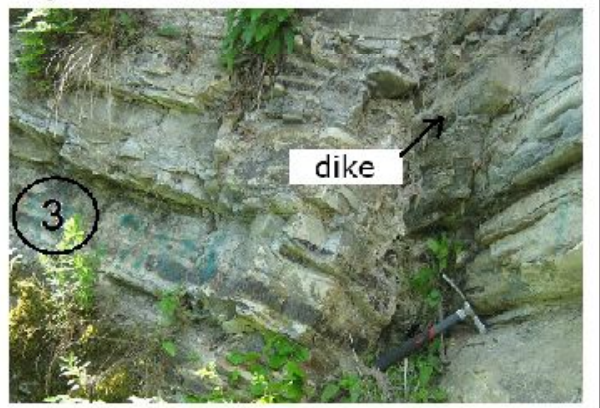

(1) horizons of the complexes of rocks: 1 - argillites and

border between the complexes

Fig. 6. Clastic dikes in outcrops of the rocks of Menilite Oligocene suite.

a - b - Geological structures in the area of the Skhidnytsia river: a) - eastern dike; b) - western dike: c) - non-plunging fold in the west area of the outcrop on the Skhidnytsia river plot; d) - dike in the outcrop in the area of Rybnik.
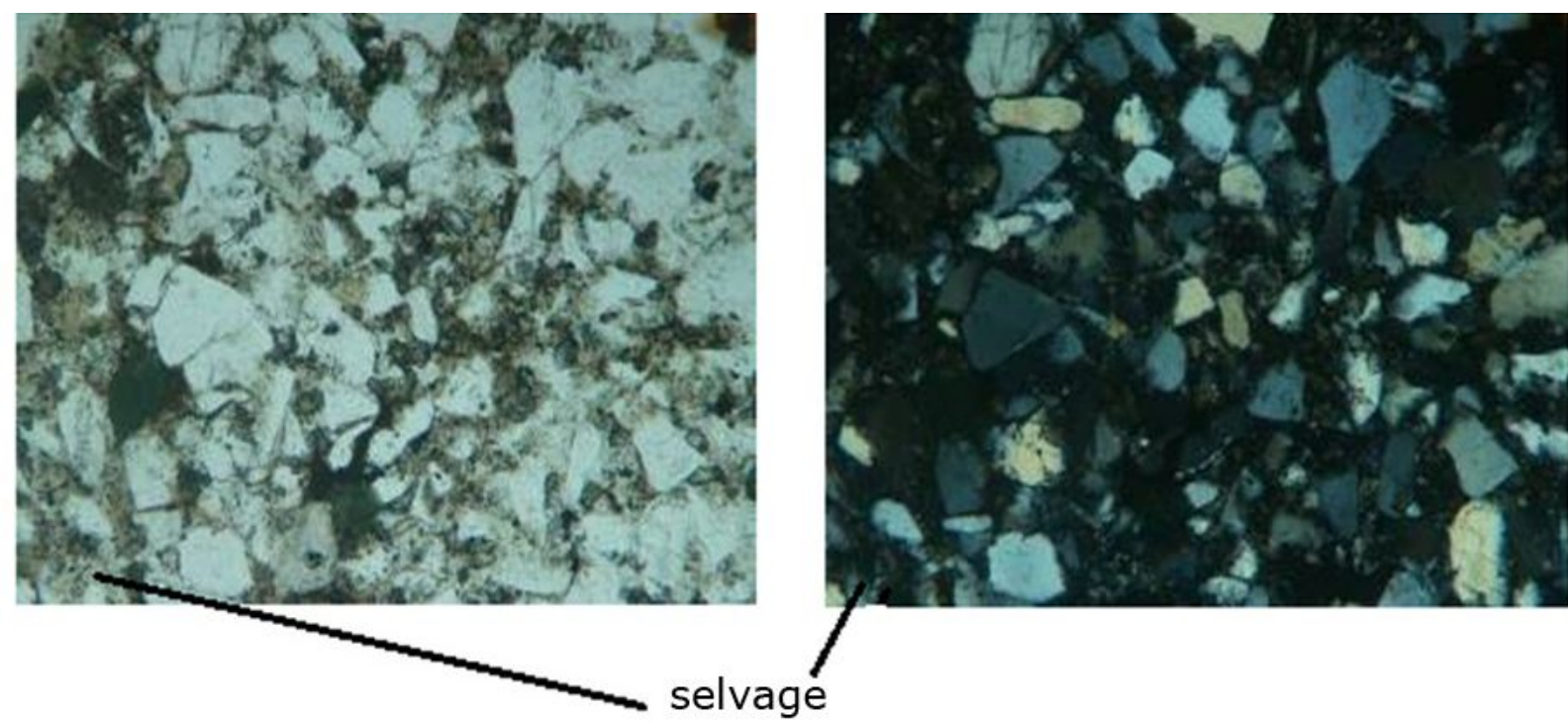

b

Fig. 7. Peculiarities of the composition and structure of the clastic dikes in the area of the Skhidnytsia.

a - white; dark-green - glauconite; black - organic compound;

b - white to dark grey - quartz; dark green - glauconite; black - organic compound.

The light which penetrates, without analyser (a) and with analyser (b).

In the dike from the area of the Rybnik near the Stryi, the proportion of the fragments and the cement was $-75 \%$ to $25 \%$. The main mineral of the fragments is quartz. The content of the quartzitic grains in the fragments is 72 to $85 \mathrm{vol} \%$. All thin sections were observed to contain glauconite in the amount of 2-3.5 vol \%. The content of organic compound in the dikes is up to $12.6 \mathrm{vol} \%$. In the selvages of the dikes, the size of the fragments rapidly decreases. Throughout the thin sections, we observed the systems of oriented microdeformations which are represented as flexible and fragile types. The microfaults are filled with organic compound. 
According to the obtained results, we can draw a conclusion that the clastic dikes in the area of the Skhidnytsia and Stryi rivers are close in mineral and petrographic composition, variability of bedding and relationship with the containing rocks. The difference is the larger amount of carbonate and organic compound in the cement of the clastic dikes in the area of the Skhidnytsia. The dikes in the area of the Stryi river are characterized by a significant number of microdeformations of mineral grains.

Conclusion. Dikes (magmatic and clastic) are a common form of bedding. Dikes are stretched bodies bordered by more or less regular surfaces. Clastic dikes are different in their filling material (allothigenic). In Ukraine, such dikes have been rather poorly studied, far more substantial results have been obtained by our foreign collegues. Within the country, clastic dikes are highly prominent in the territory of the Eastern Carpathians. The plots where the geological-structural study of the dikes was conducted are the areas of the Sukyl, Skhidnytsia and Stryi rivers. The thickness of dikes is rather variable: $3-12 \mathrm{~cm}$ in the area of the Sukyl river, $30 \mathrm{~cm}$ in the area of the Skhidnytsia, and 5-15 cm near the Stryi.

Clastic dikes in the area of the Sukyl river have a north-west strike and south-west dip direction at steep angles. Also we observed changes in the dikes" dip direction along the strike after crossing tectonic faults. The observed shifts of the ruptures were observed along the dikes. At the same time, along the tectonic fault of sub-latitudal strike, rightlateral shifts occurs in the part of the clastic dikes. These facts indicate fragile deformations of the dikes after their integration to the flysch layer.

Studying the dikes in the area of the Skhidnytsia and Stryi rivers indicated that they have a complicated morphology and are highly deformed. We observed boudinage of the dikes, shifts of dike blocks in an echelon manner in the area of the Skhidnytsia. In the area of the Rybnik, the dikes are cut by the shifts in the layers of rocks in the flint horizon. The study of the morphology of the selvages of the dikes also indicates the injection mechanism of the dikes ' formation. At the same time, the systems of orientated ridges, fissures in the selvages indicate the subhorizontal integration of the dikes ' material to the rock layer.

The injection mechanism of the dikes" integration in vertical direction is proved by the macroscopic study of a polished sample which characterizes the vertical section of dike № 5 (area of the Sukyl river). In the dikes' selvages, we found structural signs of the injection of the material upward from below. An additional proof of the injection mechanism of the formation of the dikes is a layer in the underburden rocks, which is enriched with organic compound and the enrichement of the dikes" selvages with this compound. Also, we found a sharp decrease in the sizes of the mineral grains in the area of contact with the containing rock.

According to the microscopic analyses, clastic dikes of the Skybova zona of the Eastern Carpathians are represented by aleuro-sandstones and aleurolite with quartz-carbonate cement. Aleurolite is most often represented in the pre-selvages zone of the dikes. Here, we observed a heightened content of carbonates and organic compound. Besides, in the dikes' selvages, we observed numerous microdeformations of the grains of minerals, manifested in veinlets, microfaults and microshifts with clear shift of the fragments of mineral grains, steep decrease in size of grains, increase in the content of carbonate material and organic compound. Deformed grains of quartz are characterized by wavy type of extinction during observation with the analyser. We often observed systems of orientated plastic and fragile deformations, microfaults filled with organic material. All these peculiarities, including mineralogical, indicate the formation of clastic dikes in the conditions of compression, when relatively the flexible material of the dikes" selvages (carbonates+small grains+organic compound), facilitated their integration to the layer of flysch through the system of tectonic faults of north-west strike. The formation of favorable structures for integration of clastic dikes can be related to both earthquakes and peculiarities of the field of stress and deformation of the Alpine stage of the orogeny of the Eastern Carpathians.

\section{References}

lokhin V., 2015. Deyaki osoblyvosti klastychnykh dayok Skybovoyi zony Ukrayins kykh Karpat [Some features of the clastic dikes of the Ukrainian Carpathians Skibovoy zone]. Materials of the VI conference " Physical methods in ecology, biology and medicine" Lviv, 2015, 45-47 (in Ukrainian).

lokhin V., Tikhlivets S., 2016. Uslovyya formyrovanyya y sostav klastycheskykh daek dolyny reky Sukyl (Skybovaya zona Vo-stochnykh Karpat) [Conditions of formation and composition of clastic dikes of the Sukil river valley (Skibova area of the Eastern Carpathians)]. Geol.-Mineral. Visn. Krivoriz. Nac. Univ. № 1(35), 5-14. (in Ukrainian).

Bubnyak I.M., Buchynska A., Vnuk J. et al., 2013. Heoturystychnyy putivnyk po shlyakhu Heo-Karpaty Krosno - Boryslav - Yaremche [Geo-tourist guide on the way of Geo-Carpathians Krosno-BorislavYaremche]. Collected Works. Krosno. (in Ukrainian).

Vykhot' Yu., Bubnjak I., 2011. Polya napruzhen u flishoviy tovshchi skyb Orivs koyi, Skolivs koyi ta Parashky (za doslidzhennyamy u baseyni riky Sukil ) [Fields of stress in the flysch layer of the ridges of Oryvskoy, Skolevskoy and Parascha (by 
researches in the Sukil river basin)]. Geodynamics. № 1(10). 75-82. (in Ukrainian)

Yatsuzhinsky O., Buchynska A., Skakun L. et al., 2013. HeoKarpaty - pol s ko-ukrayins kyy turysty-chnyy shlyakh [Geokarpathi - Polish-Ukrainian tourist route]. Lviv National University, 28. (in Ukrainian)

Aspler L.B., Donaldson J.A., 1985. Penecontemporaneous sandstone dykes, Nonacho Basin (Early Proterozoic, Northwest Territories): horizontal injection in vertical, tabular fissures. Canadian Journal of Earth Sciences. 23, 827-838. (in Canada)
Barmuta M., Barmuta J., Golonka J., 2014. The outcrop of the Menilite Beds in Kobielnik village - its geoeductional significance and an example of determining structural position based on clastic dykes.aria. Geotourism. V.1(36), 21-24.

Eyal Y., 1988. Sandstone dikes as evidence of localized transtension in a transpressive regime, Bir Zreir area, Eastern Sinai. Tectonics. 7, 1279-1289.

Kenkmann T., 2003. Dike formation, cataclastic flow, and rock fluidization during impact cratering: an example from the Upheaval Dome structure. Earth and Planetary Science Letters. 214, 43-58. 